\title{
Possible implications of weather variation on reproductive phenology of European common toad in southeastern Europe
}

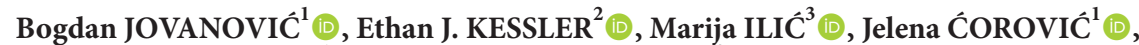

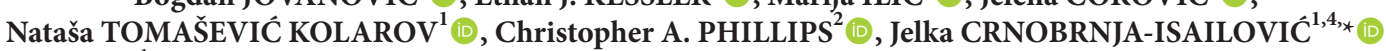 \\ ${ }^{1}$ Department of Evolutionary Biology, Institute for Biological Research "Siniša Stanković," \\ Instute of National Importance for Republic of Serbia University of Belgrade, Belgrade, Serbia \\ ${ }^{2}$ Illinois Natural History Survey, Prairie Research Institute, University of Illinois, Champaign, Illinois, USA \\ ${ }^{3}$ Department of Hydrobiology and Water Protection, Institute for Biological Research "Siniša Stanković," \\ Instute of National Importance for Republic of Serbia University of Belgrade, Belgrade, Serbia \\ ${ }^{4}$ Department of Biology and Ecology, Faculty of Sciences and Mathematics, University of Niš, Niš, Serbia
}

\begin{abstract}
Received: $31.08 .2019 \quad \bullet \quad$ Accepted/Published Online: $17.12 .2019 \quad \bullet \quad$ Final Version: 03.01 .2020
Abstract: We tracked yearly variation in breeding phenology in relation to weather parameters in a common European toad population from the southeastern part of its range. Phenological data were collected from 2001 to 2003 and from 2011 to 2017 and compared to open-access daily weather data from a nearby weather station. Data analysis revealed no significant effect of weather on initiation of breeding and a negative relationship between mean daily humidity and mean cloud cover on the duration of breeding season $(\mathrm{P}=0.03)$. Further analysis showed a decreasing trend in breeding season humidity in the past 70 years. Our results predict a tendency toward longer toad breeding seasons in years with drier winter/spring. A projected decrease in humidity in this region could prolong toad breeding season, potentially exposing adults to higher predation. Therefore, the scenario of further decline in our study population should be considered and conservation measures planned accordingly.
\end{abstract}

Key words: Bufo bufo, breeding season, weather parameters, relative humidity, duration of the breeding season

\section{Introduction}

The common European toad (Bufo bufo, Linnaeus 1758) is an early breeding anuran species that inhabits a wide range of environments (Borkin and Veith, 1997). It is also one of the most common European amphibians (Sillero et al., 2014). The trigger for the start of breeding activity in common European toads (hereafter, common toads) has been identified as both the increase of mean daily air temperature (Reading and Clarke, 1983; Kovár and Brabec, 2007) and a general increase of day length (Reading, 1998). In some parts of Europe the reproductive season of common toads is short, lasting from a few days up to two weeks (Wells, 1977; Davies and Halliday, 1979; Hemelaar, 1983; Sinsch, 1988; Reading, 1998; Sztatecsny and Schabetsberger, 2005; Hettyey et al., 2009), usually from early February to midMarch (Reading and Clarke, 1983; Reading, 1998; Voituron and Lengagne, 2008). In other parts it lasts from 24 to even 48 days, mostly occurring from March-April or extending to May (see review of Kovár and Brabec, 2007). According to Reading (1998) and references therein, common toads are considered "explosive breeders", with the peak of activity

*Correspondence: jelka@pmf.ni.ac.rs followed by decline in number of adult toads in the pond, but in some years a second small peak can be detected. Kovár and Brabec (2007), on the contrary, point to wide variation in reproductive strategy of this species, from "explosive breeders" to more "long-term breeders". Nevertheless, males usually arrive before females and females leave the breeding site soon after spawning while males stay longer (Hettyey et al., 2012).

In this study we used a dataset on common toad breeding phenology monitored at the same breeding site in southeastern Europe from 2001-2003 and 2011-2017 for a declining population (Jovanović and Crnobrnja-Isailović, 2019) to determine variation of breeding phenology milestones among years and to test its concordance with variation in weather parameters.

\section{Material and Methods}

\subsection{Study site}

We studied the breeding phenology of common toads at an artificial pond situated near the village of Zuce, Belgrade region, central Serbia $\left(44^{\circ} 40.93^{\prime} \mathrm{N}, 20^{\circ} 33.12^{\prime} \mathrm{E}, 240 \mathrm{~m}\right.$ 
a.s.l.). The pond is approximately $70 \mathrm{~m}$ long, $35 \mathrm{~m}$ wide, and $2 \mathrm{~m}$ deep, surrounded by deciduous forest, and it was constructed approximately 50 years ago by damming two streams (see Tomašević et al., 2008; Cvetković et al., 2009; Ćorović and Crnobrnja-Isailović, 2018; Jovanović and Crnobrnja-Isailović, 2019). In southern Europe and Serbia, B. bufo is also one of the most common anuran species (Arnold and Owenden, 2002; Vukov et al., 2013) and its breeding habits make it easy to observe during mating.

\subsection{Field procedures}

In 2001, 2002, and 2003 we collected data on breeding phenology in the common toad during biodiversity surveys; however, logistic constraints prevented continued monitoring. In 2011 we resumed monitoring, but for this study, only data up to 2017 were analyzed. These data were used to test a model of predicted change in duration of RANGE based on humidity (see below). Each year, we began visiting the site in early March. On every visit, we inspected the pond by walking slowly along the shore from a fixed starting point and circling the entire pond. Each year we recorded phenological milestones including: 1) arrival of first male common toad (first male day, FMD), 2) date of first amplexus (first amplexus day, FAD), 3) the day with the greatest number of observed toads (peak activity day, PAD), 4) the last day when a toad was seen in the pond (last male day, LMD), and 5) the number of days from FMD to LMD (duration of breeding season, RANGE). Due to changes in the calendar from year to year (especially leap years), all dates were recorded as days after the winter solstice (21 or 22 December), following the recommendation of Reading (2003).

Weather variables were derived from raw daily weather data available from the European Climate Assessment \& Dataset (ECA\&D; Klein Tank et al., 2002; available at www. ecad.eu) from the meteorological station at the Belgrade Observatory (44.800, 20.467; Station ID: 263; $15 \mathrm{~km}$ from the study site).

\subsection{Statistical analyses}

Because of the high correlation between the milestones FMD, FAD, and PAD, and LMD and RANGE across years (Table 1), we selected FMD and RANGE for analysis. We were trying to analyze as many uncorrelated variables as possible, and the correlation of these two with the other milestones was relatively low, especially that of FMD in comparison to PAD (see Table 1). Weather data were summarized for both the prebreeding period (determined as the period from the winter solstice until the earliest recorded FMD: 70 days) and RANGE (the period from FMD to LMD). Each year the minimum, maximum, mean, and standard deviation during the prebreeding period were calculated for each daily temperature variable, consisting of mean temperature (MET), minimum temperature
Table 1. Correlation coefficients for all breeding phenology variables. FMD = First male day, FAD = first amplexus day, $\mathrm{PAD}=$ peak activity day, $\mathrm{LMD}=$ last male day, and RANGE = breeding duration. FMD, FAD, PAD, and LMD were recorded in days since winter solstice.

\begin{tabular}{|l|l|l|l|l|}
\hline & FAD & PAD & LMD & RANGE \\
\hline FMD & 1.00 & 0.93 & 0.67 & 0.03 \\
\hline FAD & - & 0.93 & 0.65 & 0.01 \\
\hline PAD & - & - & 0.68 & 0.11 \\
\hline LMD & - & - & - & 0.76 \\
\hline & & & & \\
\hline
\end{tabular}

(MIT), and maximum temperature (MXT). Additionally, we determined the prebreeding mean of mean cloud cover (CC), mean humidity (HU), and total precipitation (PC). Maximum and minimum 7-day rolling means were also calculated for each temperature variable to model the effects of relatively prolonged extreme weather patterns. Mean values of each daily weather variable were also determined for RANGE each year.

We tested the effects of weather variables on FMD and RANGE using single-parameter linear models using $\mathrm{R}$ v.3.5.3 (R Core Team, 2019), and the Akaike information criterion (AIC) was used to rank the candidate models. For FMD analysis we used single-parameter models including year and all the weather parameters listed above, while using single-parameter models with the means of each daily weather variable and year for RANGE. Weather variables in top models explaining FMD or RANGE were extracted from the ECA\&D database dating back to 1936 (cloud cover, precipitation, and min, max, and mean temperatures) and 1949 (humidity) and were transformed to 10 -year rolling averages. These datasets were analyzed for any shifts in weather patterns which could be indicative of climate change. We estimated any potential effects on common toad breeding phenology using these models.

\section{Results}

On average, the FMD arrived at the study pond 79.5 days after the winter solstice and RANGE averaged 26.3 days (Table 2). The breeding season started earliest in 2016 (day 69), and latest in 2002 (day 96). The years with smallest RANGE were 2013 and 2015 (16 days), while the RANGE was greatest in 2003 (44 days). After the FMD, a fairly consistent progression was initiated with the FAD documented $1-3$ days later $($ mean $=2, S D=0.63)$ and PAD was noted $4-12$ days later ( mean $=8, \mathrm{SD}=2.93)$. FAD and PAD started earliest in 2016 (days 71 and 77 respectively) and latest in 2002 (days 98 and 104, respectively). There was a high correlation between these phenological variables ( $\mathrm{r}$ 
Table 2. Raw values, mean, standard deviation, minimum, and maximum values of observed breeding phenology variables. FMD = First male day, FAD = first amplexus day, PAD = peak activity day, LMD = last male day, and RANGE = breeding duration. FMD, FAD, PAD, and LMD were recorded in days since winter solstice.

\begin{tabular}{|l|l|l|l|l|l|l|l|l|l|l|l|l|l|l|}
\hline & 2001 & 2002 & 2003 & 2011 & 2012 & 2013 & 2014 & 2015 & 2016 & 2017 & Mean & SD & Min. & Max. \\
\hline FMD & 71 & 96 & 86 & 80 & 82 & 76 & 71 & 88 & 69 & 76 & 79.50 & 8.64 & 69 & 96 \\
\hline FAD & 73 & 98 & 87 & 83 & 84 & 77 & 74 & 90 & 71 & 78 & 81.50 & 8.53 & 71 & 98 \\
\hline PAD & 85 & 104 & 99 & 91 & 90 & 82 & 83 & 94 & 77 & 90 & 89.50 & 8.15 & 77 & 104 \\
\hline LMD & 95 & 122 & 130 & 97 & 120 & 92 & 102 & 104 & 102 & 94 & 105.80 & 13.36 & 92 & 130 \\
\hline RANGE & 24 & 26 & 44 & 17 & 38 & 16 & 31 & 16 & 33 & 18 & 26.30 & 9.94 & 16 & 44 \\
\hline
\end{tabular}

Table 3. Candidate models explaining the arrival of the first male common toad (FMD) ranked by $\mathrm{AIC}_{\mathrm{c}}$.

\begin{tabular}{|l|l|l|l|l|l|l|}
\hline Model & $\mathrm{AIC}_{c}$ & $\Delta \mathrm{AIC}_{c}$ & Model Lik. & AICc Wt. & LL & $\mathrm{R}^{2}$ adj. \\
\hline Intercept & 76.18 & 0.00 & 1.00 & 0.13 & -35.23 & 0.00 \\
\hline Min. daily mean temp. & 76.80 & 0.62 & 0.73 & 0.10 & -33.40 & 0.22 \\
\hline Min. daily min. temp. & 77.18 & 1.00 & 0.61 & 0.08 & -33.59 & 0.19 \\
\hline Min. daily max. temp. & 77.68 & 1.50 & 0.47 & 0.06 & -33.84 & 0.15 \\
\hline Max. daily mean temp. & 77.78 & 1.60 & 0.45 & 0.06 & -33.89 & 0.14 \\
\hline Max. daily max. temp. & 77.98 & 1.80 & 0.41 & 0.05 & -33.99 & 0.12 \\
\hline Max. daily min. temp. & 78.18 & 2.01 & 0.37 & 0.05 & -34.09 & 0.10 \\
\hline Max. 7-day mean temp. & 78.22 & 2.04 & 0.36 & 0.05 & -34.11 & 0.10 \\
\hline Max. 7-day max. temp. & 78.31 & 2.13 & 0.34 & 0.05 & -34.16 & 0.09 \\
\hline Max. 7-day min. temp. & 78.35 & 2.17 & 0.34 & 0.04 & -34.17 & 0.09 \\
\hline Mean daily min. temp. & 78.50 & 2.32 & 0.31 & 0.04 & -34.25 & 0.08 \\
\hline Year & 78.80 & 2.62 & 0.27 & 0.04 & -34.40 & 0.00 \\
\hline Min. 7-day min. temp. & 78.89 & 2.71 & 0.26 & 0.03 & -34.44 & 0.04 \\
\hline Mean daily mean temp. & 78.90 & 2.72 & 0.26 & 0.03 & -34.45 & 0.04 \\
\hline Min. 7-day mean temp. & 79.20 & 3.03 & 0.22 & 0.03 & -34.60 & 0.01 \\
\hline Mean daily max. temp. & 79.27 & 3.09 & 0.21 & 0.03 & -34.64 & 0.00 \\
\hline Min. 7-day max. temp. & 79.61 & 3.43 & 0.18 & 0.02 & -34.80 & -0.03 \\
\hline SD daily min. temp. & 80.10 & 3.92 & 0.14 & 0.02 & -35.05 & -0.08 \\
\hline SD daily max. temp. & 80.15 & 3.97 & 0.14 & 0.02 & -35.07 & -0.09 \\
\hline SD daily mean temp. & 80.23 & 4.05 & 0.13 & 0.02 & -35.11 & -0.10 \\
\hline Mean daily humidity & 80.26 & 4.08 & 0.13 & 0.02 & -35.13 & -0.10 \\
\hline Mean daily cloud cover & 80.38 & 4.20 & 0.12 & 0.02 & -35.19 & -0.12 \\
\hline Mean daily precip. & 80.41 & 4.23 & 0.12 & 0.02 & -35.20 & -0.12 \\
\hline
\end{tabular}

= 0.93-1.00; Table 1). Additionally, the LMD had relatively high correlation with RANGE $(\mathrm{r}=0.76$; Table 1$)$. LMD was earliest in 2013 (day 92) and latest in 2003 (day 130) (Table 2).

Variation in FMD was most parsimoniously explained by the intercept-only model (Table 3 ). All the minimum daily temperature models were within one $\triangle \mathrm{AIC}_{\mathrm{c}}$ with the minimum daily mean temperature explaining the most variation $\left(\mathrm{R}^{2}\right.$ adj. $\left.=0.26\right)$; however, ultimately none of these variables were significant $(P \geq 0.10)$. The top models explaining RANGE were mean daily humidity $(\beta=-0.88$, $95 \%$ CI: -1.63 to $-0.12, \mathrm{P}=0.03$ ), followed by mean daily 
cloud cover $(\beta=-7.38,95 \%$ CI: -13.92 to $-0.84, \mathrm{P}=0.03)$ (Table 4). However, these two variables were positively correlated with each other $(r=0.67)$ and are linked meteorologically; therefore, they are likely explaining similar variation in RANGE. These top models suggest that years with lower humidity and cloud cover could lead to extended RANGE (Figures 1a and 1b).

We explored trends in mean humidity from the earliest FMD and latest LMD, recorded in days post winter solstice. A linear model of the 10-year rolling average of yearly breeding season daily mean humidity showed a decrease of an estimated rate of $0.10 \% /$ year since 1949 (the first year these data were available). This relationship was significant $(\mathrm{P}<0.001)$. We used our top model for RANGE and predicted a shift in RANGE from an estimated 18.57 days for mean humidity from 1949-1958 (the first period for which a 10-year average can be calculated) to 23.80 days for mean humidity from 2008-2017.

\section{Discussion}

Our results showed that reproductive season in common toads from Zuce, Serbia, starts in March, the same as in populations from the Czech Republic, mid-Wales, and central England. Scandinavian populations breed at the end of April, while in southern England it starts in February and finishes in March (see Kovár and Brabec, 2007 and references therein). The duration of common toad breeding season in the Czech Republic, mid-Wales, and southern England is relatively long, about a month or even more, which is similar to the Serbian population analyzed in this study.

Our analyses revealed no effect of weather on the initiation of breeding activity, but a statistically significant effect of humidity on the duration of the breeding season was observed. These results do not rule out the relationship of weather on breeding initiation; rather, the limited 10-year duration of our study may have failed to adequately capture this relationship. Similar studies of breeding phenology in $B$. bufo from the western part of Europe also failed to detect significant trends in timing of breeding milestones (Reading, 2003; Prodon et al., 2017), or they confirmed mild trends depending on subsets of data subjected to analysis (Reading, 2003). Obviously, changes in amphibian reproductive phenology are

Table 4. Candidate models explaining the duration of common toad breeding season (RANGE) ranked by AIC .

\begin{tabular}{|l|l|l|l|l|l|l|}
\hline Model & $\mathrm{AIC}_{\mathrm{c}}$ & $\Delta \mathrm{AIC}_{\mathrm{c}}$ & Model Lik. & AICc Wt. & $\mathrm{LL}$ & $\mathrm{R}^{2}$ adj. \\
\hline Mean daily humidity & 76.84 & 0.00 & 1.00 & 0.36 & -33.42 & 0.41 \\
\hline Mean daily cloud cover & 77.13 & 0.29 & 0.86 & 0.31 & -33.57 & 0.39 \\
\hline Intercept & 78.98 & 2.14 & 0.34 & 0.12 & -36.63 & 0.00 \\
\hline Mean daily precip. & 79.03 & 2.19 & 0.33 & 0.12 & -34.52 & 0.26 \\
\hline Mean daily max. temp. & 82.15 & 5.31 & 0.07 & 0.03 & -36.07 & -0.01 \\
\hline Year & 82.26 & 5.42 & 0.07 & 0.02 & -36.13 & 0.00 \\
\hline Mean daily mean temp. & 82.92 & 6.08 & 0.05 & 0.02 & -36.46 & -0.09 \\
\hline Mean daily min. temp. & 83.17 & 6.33 & 0.04 & 0.02 & -36.58 & -0.11 \\
\hline
\end{tabular}
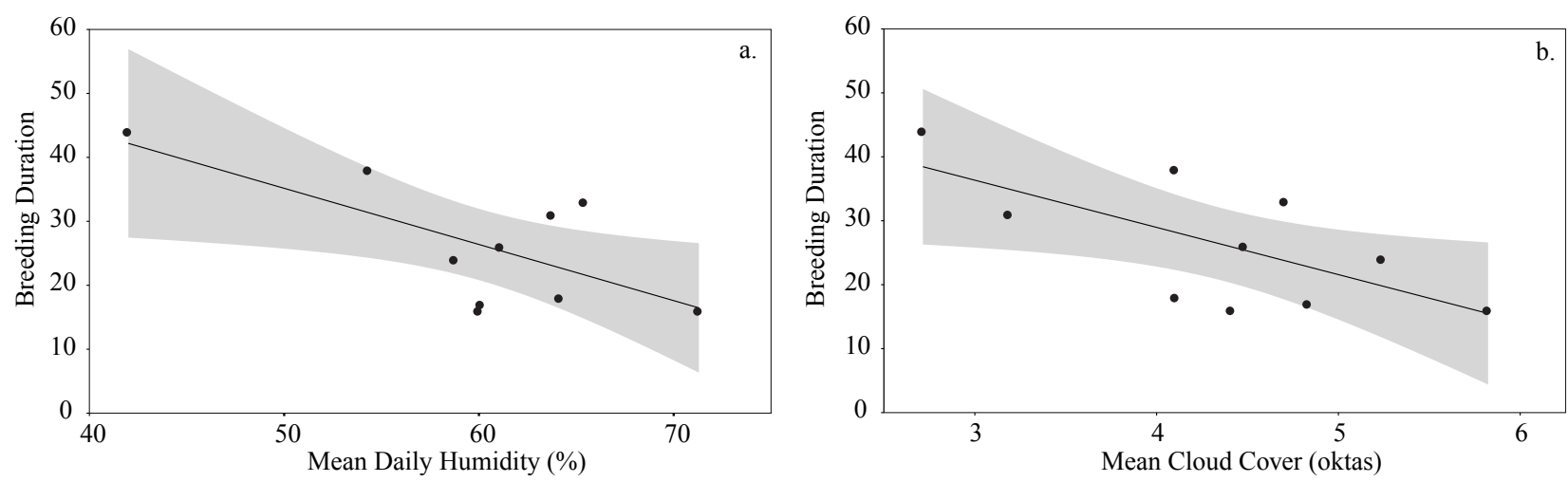

Figure 1. Modeled relation between (a) mean daily humidity (\%) and (b) mean daily cloud cover (oktas) and breeding duration (days) for the study population of common toads in Serbia. The black line and shaded region represent model estimates and $95 \%$ confidence intervals, respectively. Points are representative of raw data points. 
variable, species-specific, and, in some cases, populationspecific (Arnfield et al., 2012; While and Uller, 2014). However, we revealed an effect of humidity on breeding duration, which may have implications for this declining population.

Simmons et al. (2010) reported a trend of humidity decrease for the last decade that seems to be occurring on a global scale in terrestrial systems. In Europe, a decadeslong decrease in relative humidity has been reported in several regions. In the great Alpine region, Brunetti et al. (2009) reported a decrease of relative humidity covering 30-40 years, which occurred mostly during summer months. Brázdil et al. (2009) reported a similar trend from the Czech Republic over much of the year, with only autumn showing an increasing trend. Wypych (2010) reported decreasing summer humidity in Poland over 100 years of data collection. Vicente-Serrano et al. (2014) reported a $1 \%$ decrease per decade in relative humidity in Spain for the period of 1961-2011, with spring and summer having the highest decrease. Butler and García-Suárez (2012) reported similar findings in Northern Ireland in the period of 1965-2008. Gocić and Trajković (2013) also detected similar trends in datasets from weather stations in Serbia (four out of twelve for minimum annual relative humidity and one out of twelve for maximum annual relative humidity) from 1980-2010. Moreover, Ruosteenoja and Räisänen (2013) proposed further decreases in relative humidity in the area (as early as 2020-2049). This prediction should be considered when making recommendations for the management of the habitat surrounding this common toad breeding site: for example, more efficient protection of the vegetation cover in the habitat, together with better control and prevention of habitat degradation, will both diminish local humidity decrease and pauperization of local biodiversity. Moreover, if this common toad population has adapted to the local climate regime, as was proved for some other European anurans, then increase of landscape permeability for long-distance dispersal and therefore increased gene flow could diminish the effect of strong selection acting under contemporary climate change (see Philimore et al., 2010 and references therein).

The change of the type and strength of sexual selection could be another possible outcome of the change of breeding season length in the common toad. It was revealed that common toad mating is random when the breeding season is short; with increase of the duration of the breeding period, larger males become more advantageous, and finally, prolonged duration of the breeding season will lead to assortative mating
(Hoglund, 1989). Maximal observed duration of the breeding season was more than twice the shortest one among the years of our study; however, we would prefer to collect more data before applying such an analysis.

Although the implications of variation of breeding duration on the local common toad populations are not clear, with our study population in likely decline (Jovanović and Crnobrnja-Isailović, 2019) it is useful to consider the implications of decreasing humidity on its breeding phenology. Toads are mainly active by night, except during the breeding season, when they are quite exposed to predators such as small carnivorous mammals (Lode, 1996; Slater, 2002) or predatory birds (Olson, 1989; Jovanović et al., 2011) during the day. Olson (1989) also noted that "communal and synchronized oviposition greatly increases toad density, enhancing these geometric benefits of grouping". Consistently or frequently prolonged breeding seasons may thus result in increased adult mortality by predation, which, in the long run, could further population decline. Considering projections of relative humidity decrease in inland regions of southern Europe during winter/spring in the following decades (Ruosteenoja and Räisänen, 2013), it is reasonable to predict that the breeding period of this common amphibian species will become longer, which could expose common toads to increased predation.

Our results also support the statement that continuous long-term monitoring is necessary to clearly separate the effects of long-term trends on a target population from decadal fluctuations (Corn, 2005; Green, 2017). Specific conservation measures for common toads have not been developed yet, but this should be done before local extinctions of this species are realized.

\section{Acknowledgments and disclaimers}

This study was funded by Ministry of Education, Science, and Technological Development of the Republic of Serbia, Grant 173025 for BJ and JĆ and partially for JCI. JCI was also supported by Fulbright Short-Term Scholar Grant No G-1-00005. Permits for field work were issued by the Ministry of Environment and Spatial Planning of the Republic of Serbia No. 353-01-29/2011-03; Ministry of Environment, Mining, and Spatial Planning of Republic of Serbia No. 353-01-505/2012-03; Ministry of Energetics, Development, and Nature Protection No. 353-01-54/2013-08, No. 353-01-312/2014-08, No. 35301-42/2014; and Ministry of Agriculture and Nature Protection No. 353-01-170/2016-17 and No. 353-012666/2016-17. The authors declare that they have no conflict of interest. 


\section{References}

Arnfield H, Grant R, Monk C, Uller T (2012). Factors influencing the timing of spring migration in common toads (Bufo bufo). Journal of Zoology 288: 112-118. doi: 10.1111/j.14697998.2012.00933.x

Arnold EN, Ovenden DW (2002). Reptiles and Amphibians of Europe. 2nd ed. Princeton, NJ, USA: Princeton University Press.

Borkin LJ, Veith M (1997). Bufo bufo (Linnaeus 1758). In: Gasc JP, Cabela A, Crnobrnja-Isailović J, Dolmen D, Grossenbacher K et al. (editors). Atlas of Amphibians and Reptiles in Europe. Paris, France: Societas Europaea Herpetologica \& Museum Nationall d'Histoire Naturelle (IEGB/SPN), pp. 118-119.

Brázdil R, Chromá K, Dobrovolný P, Tolasz R (2009). Climate fluctuations in the Czech Republic during the period 19612005. International Journal of Climatology 29 (2): 223-242. doi: $10.1002 /$ joc. 1718

Brunetti M, Lentini G, Maugeri M, Nanni T, Auer I et al. (2009). Climate variability and change in the Greater Alpine Region over the last two centuries based on multi-variable analysis. International Journal of Climatology 29 (15): 2197-2225. doi: $10.1002 /$ joc. 1857

Butler CJ, García-Suárez AM (2012). Relative humidity at Armagh Observatory, 1838-2008. International Journal of Climatology 32 (5): 657-668. doi: 10.1002/joc.2302

Corn PS (2005). Climate change and amphibians. Animal Biodiversity and Conservation 28: 59-67.

Ćorović J, Crnobrnja-Isailović J (2018). Aspects of thermal ecology of the meadow lizard (Darevskia praticola). Amphibia-Reptilia 39: 229-238. doi: 10.1163/15685381-17000218

Cvetković D, Tomašević N, Ficetola GF, Crnobrnja-Isailović J, Miaud C (2009). Bergmann's rule in amphibians: Combining demographic and ecological parameters to explain body size variation among populations in the Common toad Bufo bufo. Journal of Zoological Systematics and Evolutionary Research 47: 171-180. doi: 10.1111/j.1439-0469.2008.00504.x

Davies NB, Halliday TR (1979). Competitive mate searching in male common toads Bufo bufo. Animal Behaviour 27: 1253-1267. doi: 10.1016/0003-3472(79)90070-8

Gocić M, Trajković S (2013). Analysis of changes in meteorological variables using Mann-Kendall and Sen's slope estimator statistical tests in Serbia. Global Planet Change 100: 172-182. doi: 10.1016/j.gloplacha.2012.10.014

Green DM (2017). Amphibian breeding phenology trends under climate change: Predicting the past to forecast the future. Global Change Biology 23: 646-656. doi: 10.1111/gcb.13390

Hemelaar SM (1983). Age of Bufo bufo in amplexus over the spawning period. Oikos 40: 1-5. doi: 10.2307/3544193

Hettyey A, Vági B, Hévizi G, Török J (2009). Changes in sperm stores, ejaculate size, fertilization success, and sexual motivation over repeated matings in the common toad, Bufo bufo (Anura: Bufonidae). Biological Journal of Linnean Society 96: 361-371. doi: 10.1111/j.1095-8312.2008.01126.x
Hettyey A, Vági B, Török J, Hoi H (2012). Allocation in reproduction is not tailored to the probable number of matings in common toad (Bufo bufo) males. Behavioral Ecology and Sociobiology 66: 201-208. doi: 10.007/s00265-011-1267

Hoglund J (1989). Pairing and spawning patterns in the common toad, Bufo bufo: the effects of the sex ratios and the time available for male-male competition. Animal Behaviour 38: 423-429. doi: 10.1016/S0003-3472(89)80035-1

Jovanović B, Crnobrnja-Isailović J (2019). Fluctuations in population abundance in two anurans from Central Serbia. Herpetozoa 32: 65-71. doi: 10.3897/herpetozoa.32.e35660

Jovanović O, Šafarek G, Samardžić M (2011). A field observation of common buzzard predating on common toad. Hyla 2011: 3738.

Klein Tank AMG, Wijngaard JB, Können GP, Böhm R, Demarée G (2002). Daily dataset of 20th-century surface air temperature and precipitation series for the European Climate Assessment. International Journal of Climatology 22 (12): 1441-1453. doi: 10.1002/joc.773

Kovář R, Brabec M (2007). Reproduction strategy of Bufo bufo (Amphibia: Anura) in the Strnady breeding pond, Czech Republic. Acta Societatis Zoologicae Bohemicae 71 (3-4): 173192.

Lode T (1996). Polecat predation of frogs and toads at breeding sites in Western France. Ecology, Ethology \& Evolution 8: 115-124. doi: 10.1080/08927014.1996.9522922.

Olson DH (1989). Predation on Breeding Western Toads (Bufo boreas). Copeia 1989: 391-397. doi: 10.2307/1445435

Phillimore AB, Hadfield JD, Jones OR, Smithers RJ (2010). Differences in spawning date between populations of common frog reveal local adaptation. Proceedings of the National Academy of Sciences of the USA 107: 8292-8297.

Prodon R, Geniez P, Cheylan M, Devers F, Chuine I et al. (2017). Reversal of the shift towards earlier spring phenology in several Mediterranean reptiles and amphibians during the 1998-2013 warming slowdown. Global Change Biology 23: 5481-5491. doi: $10.1111 /$ gcb.13812

R Core Team (2019). A Language and Environment for Statistical Computing. Vienna, Austria: R Foundation for Statistical Computing.

Reading CJ (1998). The effect of winter temperatures on the timing of breeding activity in the Common toad Bufo bufo. Copeia 4: 469-475. doi: 10.1007/s004420050682

Reading CJ (2003). The effects of variation in climatic temperature (1980-2001) on breeding activity and tadpole stage duration in the common toad, Bufo bufo. Science of the Total Environment 310: 231-236. doi: 10.1016/S0048-9697(02)00643-5

Reading CJ, Clarke RT (1983). Male breeding behaviour and mate acquisition in the common toad, Bufo bufo. Journal of Zoology 201: 237-246. doi: 10.1111/j.1469-7998.1983.tb04273.x 
Ruosteenoja K, Räisänen P (2013). Seasonal changes in solar radiation and relative humidity in Europe in response to global warming. American Meteorological Society 26: 2467-2481. doi: 10.1175/JCLI-D-12-00007.1

Sillero N, Campos J, Bonardi A, Corti C, Creemers R et al. (2014). Updated distribution and biogeography of amphibians and reptiles of Europe. Amphibia-Reptilia 35: 1-31. doi: 10.1163/15685381-00002935

Simmons AJ, Willett KM, Jones PD, Thorne PW, Dee DP (2010). Low-frequency variations in surface atmospheric humidity, temperature, and precipitation: Inferences from reanalyses and monthly gridded observational data sets. Journal of Geophysical Research: Atmospheres 115 (D1): D01110. doi: 10.1029/2009JD012442

Sinsch U (1988). Seasonal changes in the migratory behaviour of the toad Bufo bufo: Direction and magnitude of movements. Oecologia 76: 390-398. doi: 10.1007/BF00377034

Slater F (2002). Progressive skinning of toads (Bufo bufo) by the Eurasian otter (Lutra lutra). IUCN Otter Specialist Group Bulletin 19: 25-29.

Sztatecsny M, Schabetsberger R (2005). Into thin air: vertical migration, body condition, and quality of terrestrial habitats of alpine common toads, Bufo bufo. Canadian Journal of Zoology 83: 788-796. doi: 10.1139/z05-071
Tomašević N, Cvetković D, Aleksić I, Miaud C, Crnobrnja-Isailović J (2008). Interannual variation in life history traits between neighbouring populations of the widespread amphibian Bufo bufo. Revue d'Écologie (la Terre \& la Vie) 63: 73-83.

Vicente-Serrano SM, Lopez-Moreno JI, Beguería S, Lorenzo-Lacruz J, Sanchez-Lorenzo A et al. (2014). Evidence of increasing drought severity caused by temperature rise in southern Europe. Environmental Research Letters 9 (4): 044001. doi: 10.1088/1748-9326/9/4/044001

Voituron Y, Lengagne T (2008). Freezing before mating severely affects the fitness of a capital breeder. Physiological Biochemical Zoology 81: 204-210. doi: 10.1086/527422

Vukov T, Kalezić ML, Tomović L, Krizmanić I, Jović D et al. (2013). Amphibians in Serbia - Distribution and diversity patterns. Bulletin Natural History Museum Belgrade 6: 90-112. doi: 10.5937/bnhmb1306090V

Wells KD (1977). The social behaviour of anuran amphibians. Animal Behaviour 25: 666-693. doi: 10.1016/0003-3472(77)90118-X

While GM, Uller T (2014). Quo vadis amphibia? Global warming and breeding phenology in frogs, toads and salamanders. Ecography 37: 921-929. doi: 10.1111/ecog.00521

Wypych A (2010). Twentieth century variability of surface humidity as the climate change indicator in Kraków (Southern Poland). Theoretical and Applied Climatology 101 (3-4): 475-482. doi: 10.1007/s00704-009-0221-y 